\title{
Teaching and learning process to enhance teaching effectiveness: a literature review
}

\author{
Afzal Sayed Munna*1, Md Abul Kalam² \\ ${ }^{1,2}$ School of Business, University of Wales Trinity Saint David, Winchester House, 11 Cranmer Rd, Vassal, London, UK \\ *Corresponding author: a.munna@uwtsd.ac.uk
}

\begin{abstract}
Teaching and learning process can be defined as a transformation process of knowledge from teachers to students. It is referred as the combination of various elements within the process where an educator identifies and establish the learning objectives and develop teaching resources and implement the teaching and learning strategy. On the other hand, learning is a cardinal factor that a teacher must consider while teaching students. The paper evaluated various academic journals, pedagogy, and inclusive practices to assess the teaching effectiveness within the higher education setting. The objective of the research is to assess the teaching effectiveness in a higher education setting. The research used experimental research methods (primarily reflection) using literary forms to analyse the theory with the reinforcement of the practice from the university experiences. The research findings suggest that providing positive and adequate formative and developmental feedback, introduction of role-play has a profound positive impact on the students' confidence and self-esteem. It was also revealed that, active learning environment promotes inclusivity and improve the faculty and student academic performances. The research findings will enable the educators to help create and implement an inclusive teaching and learning environment to improve the learner's expectation and academic performance.
\end{abstract}

\section{Keywords:}

Teaching; learning; effectiveness.

\section{INTRODUCTION}

Learning can be considered as change that is permanent in nature because change is brought into students by a teacher through techniques like developing specific skills, changing some attitudes, or understanding specific scientific law operating behind a learning environment (Sequeira, 2012). However, in order to be an active learner in higher education, each student expects to be treated as an adult learner who has some right over the learning ambience in the form of asking questions and clearing of doubts (Michael, and Modell, 2003). That is, students expect to have ownership over the learning session (Mitra, 2008; Pond \& Rehan, 1997). Moreover, students also want their instructor to be cooperative and humorous who would teach clearly and usually use relevant examples so that the course material being taught becomes easy to understand, which I think is increasingly being required in classrooms today (Becker et al., 1990).

The research was initiated with the desire to complete the professional development milestone. The area of interest was a key factor for both the researcher's current academic practice. As university lecturers, we have been in a continuous dialogue to see how we can ensure continuous improvement at our everyday lesson and thus realized an immense study that needs to be done in inclusive practice. With our current involvement in the higher education settings, we often use the term 'inclusive education' that sounds synonymous with education for children with disabilities, however, we have tried to look at the learning barriers in our higher education setting and found many mature students feel that they have barriers to learning. Multiple higher education research explored that the inclusion and equity in teaching and learning resulting in policy makers and scholars have been discussing the importance of widening participation in tertiary education (e.g., Bradley \& Miller, 2010). Therefore, we always felt that promoting inclusive teaching and learning through different pedagogical approaches may not be enough. It is essential to ensure inclusive education in designing curricula and assessment by ensuring that our teaching and learning process enhance our teaching effectiveness and can also be used as a medium to eliminate barriers to education to include all students. The research mainly addressed to analyze the factors responsible for creating a process to ensure effectiveness in teaching and learning. This study aims to analyze the teaching and learning process to ensure effectiveness. Hence, the research question is proposed: How to create an inclusive teaching and learning environment to ensure effectiveness?

\section{Methodology}

We have considered that case study methods remained a controversial approach to data collection, however, after considering its wide range of validity in many social science studies especially when in-depth explanations of social behavior we have decided to choose case study as our research methods. In this article we have used the case study from one of the universities based in London, United Kingdom. The case study approach allowed the researchers to gather indepth understanding on the concept. Thus, the work collected data using secondary sources and used mainly various peerreviewed journal articles and various government and agency publications. The researchers also used personal reflection from the higher education practice. The measure of reflection explored the experimental research methods (primarily reflection) using literary forms. To support our research and investigation we have designed questionnaire to collect data from our students. Because of limited number of learners of the disciplines, questionnaire has been designed based on qualitative data collection method. Data has been analyzed to get the perceptions of learners about effective delivery of modules. However, to ensure accuracy of our research and findings we have also applied data triangulation methods by mapping our research findings with similar research and case studies of other researchers. 


\section{RESULTS AND DisCUSSION}

The findings of the current research revealed that it is a teacher responsibility to ensure regular interaction occurs between the basic human capabilities of a learner and the culturally invented technologies so that it finally leads to enhancement in their cognitive capabilities. In line with this theory's principles, the use of class interaction, role play and visual simulation to the students in the form of graphs, charts, and newspapers from where information on various business and financial matters challenged their learnings and allowed them to become more creative. In terms of resources, the research found that teachers need to use various resources in the learning process that may include computers, books, smartboard, equipment, artefacts, whiteboard, special speakers, games, computer programs etc. It was evident from the research that the more the lesson is interactive, the more the learners are engaged/motivated to improve their learning experiences. The research also realized that certain teaching methods might be very useful for certain learners which may be flawed for other. Thus, it is recommended to use a blended learning (mixture of online and offline learning) along with experiential learning (cross-age peer tutoring, pro and con grid, prodigy games, mnemonic) which have been very useful in improving the learning experience and reducing the disruptive issues in the classroom from the case study.

Based on previous knowledges about student learning, we questioned students what they found most fascinating about a learning session and what outcomes would they aspire to achieve from the teaching-learning session. In response to these questions, different students came up with different answers which indicated that different students implemented different learning styles in order to be active participant in the teaching-learning session and gain significant learning outcomes. We also apprehended from the responses of the students that learning outcome is also dependent upon the learner types. In a classroom setting in specific, there are certain specific types of learners. One of them is the group of auditory learners who feel more confident in receiving and interpreting auditory stimulus. This category of learners' benefits best from the instructions that students receive through classroom lectures, discussion sessions, and group sessions. In this context, (Coffield, 2013) opines that the quality of teaching and learning is often compromised due to lack of constant up-gradation in knowledge on the subject or issue. We agreed with this sentiment, since we have witnessed first-hand that innovation and continuous learning is the primary way to ensure success in teaching.

Another category of learners in a classroom is the visual learners who best respond to visual learning stimuli. Besides learning from these visual stimuli, visual learners also learn by observing what others do in a learning session. This category of learners learns best when they are given visual learning stimuli like charts, diagrams, pictures, or formulae written on the blackboard. This category of learners is usually creative in applying their learning outcomes, observant in nature and not easily distracted (Arthurs, 2007; Gilakjani, 2012). The third category of learners that is often found in a classroom learning session is the kinesthetic learner. Learners in this category are more comfortable in learning through hands-on approach rather than visual or auditory learning. Thus, they learn best when teachers give them instructions through physical activities.

In most cases, they present their learning outcomes through physical activities too (Leopold, 2012). Nevertheless, from their responses to the questions we also understood that some internal and external factors are at play behind the learning objectives and expected learning outcomes of the students. Due to the positive experience that we have had using this strategy, as well as similar opinions from our colleagues, we recommend that inclusion of practical activities in the lesson can be an integral part of every course and curriculum.

As we have been teaching different modules to the students at the universities and colleges, to a great extent, we must use variety of teaching approaches depending on the learning styles of the students. With the use of a questionnaire (VARK- Visual, Aural, Read/Write, and Kinesthetic) developed by Neil Fleming (2001) for a moderately large group of learners, we understood that there is a mixed of three preferred style of learners. We initially started teaching with the use of PowerPoint slides followed by a group discussion in the class. Auditory learners have been helped with this teaching strategy as they have been able to understand the concept of relevant costing by listening to our lecture and discussing the matter with their peers. We used video clips from YouTube along with a TedTalk lecture to reinforce the concept and highlight the different use of relevant costing approach which ultimately helped the visual learners.

We also printed the PowerPoint slides along with some case study scenarios for the learners which helped the learners with visual preference. Finally, we created some exam-type questions for the learners which required the learners to roleplay. It ultimately enhanced the learning experience of kinesthetic learners. That is, depending on the learning styles, we try to incorporate variety of teaching and learning strategies and approaches while the main intention is to ensure equal opportunity for the learners so that they can understand the subject contexts and actively participate during the lesson. Most importantly, we tried to promote engaging and creative learning environment for the students of different learning styles. Not only did this promote the rate of participation of the students in my class, but also found that many of them came up with out-of-the-box ideas which prompted me to learn new approaches to the management course, such as, cultural activities affected by political events. Among the cardinal internal factors that affect learning performance of student include age, gender, heredity, cognitive intelligence, and individual learning facilities. Among the external factors that affect learning performance of the students are the mode and method of instruction given by the teacher, qualification of the teacher, peer influence on the students, and teacher-student ratio in a learning session (Singh, Malik, \& Singh, 2016; Petty, 2009).

The Behaviorist Approach that eminent American psychologist J.B. Watson introduced in 1913 is one of the theories. This theory's principal focus is the concept of conditioning through imitation (Watson \& Rayner, 1920). We have found this approach to be particularly useful in class in numerous instances. During classroom interactions we routinely recall that people tend to associate typical sounds and words through experience and objects. We are also aware that people tend to associate certain feelings and emotions with certain situations, symbols, and objects that they come across in their daily 
lives. Keeping with this principle, we have repeatedly strived to create an ambience where there will be conditioning through imitation, and this is only possible when we physically demonstrated to the students how to solve problems or approach certain problematic situations.

The next theory that can be associated with classroom teaching-learning is the Two Factor Theory which is also known as the Motivation-Hygiene Theory or Dual Factor Theory. Herzberg proposed in 1957, cited in Adair (2009), who simultaneously indicated some learning motivators, like challenging nature of work, recognition of employee performance, and the possibility of new opportunities from the work, exciting work, and employee involvement decisionmaking processes. This theory, to a great extent, is very useful in managing classroom behavior. If the learners find interest in learning something, it becomes easy for the teachers to teach them.

Another theory that can be well implemented in a teaching-learning scenario is Bruner's Theory of Development. This theory was proposed by the eminent cognitive psychologist Jerome Burner in 1957 and proposed that the basic objective of education should be to promote intellectual development in the learners. According to Bruner (1957, p. 234), "generic coding systems that permit one to go beyond the data to new and possibly fruitful predictions". The theory also proposed that when cognitive development is encouraged in the learner, it manifests in the form of his or her ability to think intellectually.

\section{CONCLUSION}

It is found from the personal reflection and class observation that for managing the behavior of individuals or groups different strategies may have to be used such as questioning, role play, rewards, punishment, discussions, paired/group work, observations, switching activities, audio/visuals etc. The teachers' dynamics need to be understood by the teachers, and behaviors or teaching approaches need to be adjusted. Again, learning needs, methods or styles of the learners may be different; in this respect, teachers need to understand the need and preferences of the learners and prepare the lesson plan accordingly to meet the learning objective of all learners rather than certain individuals. Most importantly, teachers need to identify the learning barriers as quickly as possible. For example, sometimes students are disruptive as they have some barriers including language barrier, low self-esteem, confidence, feeling of being inappropriate etc. In this case, rather than giving them warnings, it is better for the teachers to know the underlying causes and respond accordingly.

Positive feedback, sometimes, play role as tonic in having profound positive impact on the confidence and self-esteem of the students. Finally, it is essential for the teachers to enhance student engagement through active learning, to promote student inclusivity through the learning process (experiential and blended learning) and to match outcome with the faculty and student expectations through assessments. They might easily be possible for the teachers to do so, if they can be able to communicate effectively, be in control, be consistent with the rules, provide choice and adjust themselves and finally be creative in managing behavior

\section{REFERENCES}

Adair, J. (2009). Leadership and motivation: the fifty rule and the eight key principles of motivating others, London: Kogan Page.

Alfayad, Z., Arif, L. S. (2017). Employee Voice and Job Satisfaction: An Application of Herzberg Two-factor Theory. International Review of Management and Marketing 7, 150-156.

Alfieri, L., Brooks, P. J., Aldrich, J., Tenenbaum, H. (2011). Does discovery-based instruction enhance learning? Journal of Educational Psychology 103.

Arthurs (2007). A juggling act in the classroom: Managing different learning styles. Teaching and learning in nursing 2.

Becker, A., Davis, S., McGregor, L., Grover, C. (1990). Student Expectations of Course and Instructor. Teaching Psychology 17, 59162.

Bruner, J. S. (1957). Going beyond the information given. New York: Norton.

Ellis, S. and Tod, J. (2015). Promoting behaviour for the learning in the classroom: Effective strategies, personal style, and professionalism. Routledge: London.

Gray, C., and MacBlain S. (2012). Learning theories in childhood. Sage Publications Ltd: London.

Garver, R., Noguera, P. (2012). For Safety's Sake: A Case Study of School Security Efforts and Their Impact on Education Reform. Journal of Applied Research on Children: Informing Policy for Children at Risk 3.

Gilakjani, A. (2012). Visual, auditory, kinaesthetic learning styles and their impacts on English language teaching. Journal of studies in education 2, 104-113.

Hackman, J.R. Oldham, G.R., (1976). Motivation Through the Design of Work: Test of a Theory. Organizational behaviour and human performance 16, 250-276.

Johnston, H. (2012). The Spiral Curriculum. Education Partnership Inc., Florida.

Kiel, J., (1999). Reshaping Maslow's hierarchy of needs to reflect today's educational and managerial philosophies. Journal of Instructional Psychology 26, 167.

Leopold, L. (2012). Prewriting tasks for auditory, visual, and kinaesthetic learners. TESL Canada Journal 29.

McLeod, S. (2008). Bruner's Three Modes of Representation. Simply Psychology.

Michael, J. A. and Modell, H. I. (2003). Active learning in college and science classrooms: A working Model helping the learner to learn. Lawrence Erlbaum Associates Publishers: London.

Mitra, D. (2008). Amplifying student voice. Educational Leadership 66.

Moayyeri, H. (2015). 'The Impact of Undergraduate Students' Learning Preferences (VARK Model) on Their Language Achievement', Journal of Language Teaching \& Research, 6, 1, pp. 132-139, Education Research Complete, EBSCOhost.

Oelze, P. (2018). John B. Watson And Behaviourism.

Petty, G. (2009). Teaching today: a practical guide. $4^{\text {th }}$ ed. Nelson Thorns Ltd: Cheltenham.

Pond, K., Rehan, U. (1997). Learning to assess students using peer review. Studies in Educational Evaluation 24, 331-348.

Rogers, B. (1995). Classroom behaviour: A practical guide to effective teaching, behaviour management and colleague support. $4^{\text {th }}$ ed. Sage: London. 
Schunk, D. H. (2009). Learning theories: An educational perspective. $5^{\text {th }}$ ed. Pearson education Ltd.: London.

Sequeira, A. (2012). Introduction to Concepts of Teaching and Learning. National Institute of Technology Karnataka, Surathkal, India.

Shaw, S., Gomes, P., Polotskaia, A., Jankowska, A. (2015). The relationship between student health and academic performance: Implications for school psychologists. School Psychology International 36.

Singh, S., Malik, S., Singh, P. (2016). Factors Affecting Academic Performance of Students. PPARIPEX - Indian Journal of Research 5.

Sule, K. (2013). An Evaluation of The Motivation Levels of Primary School Teachers. E-journal 4.

Uysal, H.T., Aydemir, S., Genç, E. (2017). Maslow's Hierarchy of Needs In 21st Century: The Examination of Vocational Differences, in: Research on Science and Art in 21st Century. Gece Kitaplığ1.

Watson, J. B. \& Rayner, R. (1920). Conditioned emotional responses. Journal of Experimental Psychology, 3, 1-14. 